\title{
FENOMENA ITSBAT NIKAH TERHADAP PERKAWINAN YANG DILAKUKAN SETELAH TERBITNYA UNDANG-UNDANG NOMOR 1 TAHUN 1974 TENTANG PERKAWINAN (STUDI DI PENGADILAN AGAMA ANDOOLO)
}

\author{
Andi Nadir Mudar \\ BKPRMI Kota BAUBAU Priode 2015-2018 \\ Email: nadirmudar@gmail.com
}

\begin{abstract}
Abstrak
Fenomena itsbat nikah terhadap perkawinan yang dilakukan setelah terbitnya Undang-undang Nomor 1 Tahun 1974 tentang Perkawinan di Pengadilan Agama Andoolo merupakan suatu hal yang sangat penting dilkakukan untuk mengetahui kondisi obyektif itsbat nikah, faktor penyebab dan pandangan Hakim serta perilaku dan alasan masyarakat mengajukan Itsbat Nikah dengan berbagai dampaknya. Penelitian ini adalah penelitian deskriptif kualitatif, dengan menggunakan metode pendekatan yuridisempiris, sumber data primer dan sekunder melalui observasi, wawancara, menelaah berbagai buku, arsip putusan/penetapan PA Andoolo, website serta regulasi yang terkait dan relevan dengan penulisan ini. Hasil penelitian bahwa kondisi obyektif Itsbat Nikah bersifat fluktuatif, alasan dan faktor penyebab diantaranya; jarak yang jauh dan sulit dijangkau, kelalaian PPPN, kawin paksa, pandangan hakim bahwa itsbat nikah tidak bisa dilarang sepanjang memenuhi rukun dan syarat sah pernikahan serta dapat dibuktikan dipersidangan. Dampak itsbat nikah yakni berdampak positif dan negatif, lemahnya pengawasan pencatatan nikah, serta KHI member peluang bagi masyarakat mengajukan Itsbat Nikah, akibatnya pelaksanaan UUP tidak berlaku secara efektif dan efesien.
\end{abstract}

Kata Kunci: Fenomena,Itsbat Nikah, Undang-undang Nomor 1 Tahun 1974, Perkawinan.

\begin{abstract}
Itsbat phenomenon Marriage to marriage conducted after the issuance of Law No. 1 of 1974 concerning Marriage in Andoolo Religious Court is a very important thing to do to find out the objective conditions of the Marriage Marriage, the causes, and the views of the judge, as well as the behavior and reasons of the people proposing Itsbat Marriage with various effects. This research is a descriptive qualitative research using a juridical-empirical approach, primary and secondary data sources through observation, interviews, reviewing various books, archives of decisions by Andoolo PA, websites and regulations related and relevant to this writing. The results of the study that the condition of Itsbat Nikah is fluctuating, the reasons and the causative factors include; long distances and hard to reach, negligence of PPPN, forced marriage, the view of the judge that the Marriage Principle cannot be prohibited as long as it fulfills the pillars and legal requirements for marriage and can be proven in court. The impact of the Marriage Marriage has a positive and negative impact, a weak supervision of marriage registration, and KHI provides an opportunity for the community to propose
\end{abstract}


a Marriage Certificate, as a result the implementation of the Law is not effective and efficient.

Keywords: Phenomenon, Itsbat Marriage, Law Number 1 Year 1974, Marriage

\section{Pendahuluan}

Perkawinan merupakan suatu hal yang penting dalam realitas kehidupan ummat manusia. Dengan adanya Perkawinan rumah tangga dapat ditegakkan dan dibina sesuai dengan norma Agama dan tata kehidupan bermasyarakat. Dalam Agama samawi, Perkawinan mendapat tempat yang sangat terhormat dan sangat terjunjung tinggi tata aturan yang telah ditetapkan dalam kitab suci. Demikian juga negara-negara yang menjunjung tinggi nilai-nilai moral, masalah Perkawinan merupakan suatu hal yang sangat prinsip dalam suatu kehidupan masyarakat, dan sangat dihormati aturan pelaksanaan sehingga pelaksanaan Perkawinan itu sesuai dengan norma dan prinsip yang telah disepakati bersama ${ }^{1}$.

Masalah Perkawinan di Indonesia merupakan hal yang sangat penting dalam kehidupan berbangsa dan bernegara, sehingga pemerintah sejak Proklamasi Kemerdekaan hingga sekarang menaruh perhatian yang sangat serius dalam hal Perkawinan ini. Hal ini ditandai banyaknya aturan perundang-undangan yang telah dibuat untuk mengatur masalah Perkawinan ini, terakhir adalah lahirnya Undang-undang Nomor 1 Tahun 1974 tentang Perkawinan dan PP Nomor 9 Tahun 1975 serta beberapa peraturan lain yang intinya mengatur tentang Perkawinan agar dilaksanakan sesuai dengan peraturan yang telah ditetapkan $i^{2}{ }^{2}$. Namun realitas kehidupan sosial masyarakat tidak selamanya berbanding lurus dengan fakta hukum yang berlaku ditengah masyarakat, hal ini dapat dilihat dalam suatu komunitas masyarakat yang berada diwilayah Kabupaten Konawe Selatan provinsi Sulawesi Tenggara, sehingga dalam penelitian ini akan membahas tentang hubungan antara perilaku masyarakat yang melakukan penyimpangan hukum dengan peraturan dan perundang-undangan yang ada.

Perilaku masyarakat yang dimaksud adalah permohonan isbat nikah pada Perkawinan yang dilakukan setelah terbitnya Undang-undang Nomor 1 Tahun 1974 tentang Perkawinan di Pengadilan Agama Andoolo. Penyebabnya bukan hanya karena

\footnotetext{
${ }^{1}$ Abdul Manan, Aneka Masalah Hukum Perdata Islam di Indonesia,Cet. Ke-4, Jakarta: Kencana Prenadamedia Group, 2006, h. 1-2

${ }^{2}$ Abdul Manan, Aneka Masalah..., h. 2-3
} 
kelalaian yang dilakukan oleh pasangan suami istri tersebut, atau kelalaian dari pihak keluarga maupun orang tua calon mempelai, maupun kelalaian pihak pegawai pencatat nikah, namun akan tetapi seolah ada asumsi bahwa pernikahan yang mereka lakukan telah sah secara Agama dan dianggap sudah cukup, serta maraknya pula tradisi ditengah masyarakat peristiwa Perkawinan dibawah umur yang tidak sesuai dengan standar usia minimal calon mempelai sebagaimana yang ditetapkan oleh negara berdasarkan Undangundang Perkawinan.

Terkait dengan perihal tersebut, maka selanjutnya dapat ditelusuri dalam peraturan-peraturan yang ada. Menurut Undang-undang Nomor 1 Tahun 1974 tentang Perkawinan dalam Pasal 1 menyatakan bahwa:

"Perkawinan adalah ikatan lahir batin antara seorang pria dan seorang wanita sebagai suami istri dengan tujuan membentuk keluarga atau rumah tangga yang bahagia dan kekal berdasarkan Ketuhanan yang Maha Esa".

Selanjutnya dalam Pasal 2 ayat 1 menyatakan bahwa Perkawinan yang sah adalah apabila Perkawinan yang dilakukan menurut hukum masing-masing Agama dan kepercayaanya $\mathrm{itu}^{3}$. Sehingga dengan demikian, dari kedua Pasal tersebut, dapatlah disimpulkan bahwa Perkawinan dianggap sah menurut Agama Islam adalah Perkawinan yang telah memenuhi syarat dan rukun Perkawinan, yaitu terdapat calon suami, calon istri, wali nikah, dua orang saksi,akad ( ijab dan Kabul) serta adanya mahar atau mas kawin.

Kemudian pada aspek lain, untuk menjamin tertib administrasi maka setiap peristiwa Perkawinan bagi masyarakat muslim khususnya, haruslah dicatat oleh Pegawai Pencatat Nikah yang berwenang pada Kantor Urusan Agama (KUA) setempat dimana terjadinya Perkawinan. Dalam Agama Islam, memang pada dasarnya tidak ada perintah yang secara tegas, baik itu dalam Al-Qur'an ataupun Hadits Nabi, yang menunjukkan secara langsung adanya pencatatan Perkawinan. Akan tetapi, jika dilihat dari segi urgensi dan fungsinya, pencatatan Perkawinan itu perlu dilakukan demi untuk menjaga ketertiban administrasi kependudukan dan keperluan administrasi pemerintahan. Hal inilah yang kemudian selanjutnya diatur pada Pasal 2 ayat (2), "Tiap-tiap Perkawinan dicatatkan menurut peraturan perundang-undangan yang berlaku."4 Sementara itu didalam Kompilasi Hukum Islam dijelaskan dalam Pasal 5, yaitu agar terjamin ketertiban Perkawinan bagi masyarakat Islam, setiap Perkawinan harus dicatat. Pencatatan Perkawinan tersebut dilakukan oleh Pegawai Pencatat Nikah sebagaimana diatur dalam

\footnotetext{
${ }^{3}$ Undang-undang RI Nomor 1 Tahun 1974 tentang Perkawinan Pasal 1 dan 2 ayat (1)

${ }^{4}$ Pasal 2 ayat (2)
} 
Undang-undang No. 22 Tahun 1946 jo. Undang-undang No. 32 Tahun 1954 tentang Pencatatan Nikah, Thalak dan Rujuk. ${ }^{5}$

Pencatatan Perkawinan bertujuan untuk mewujudkan ketertiban Perkawinan dalam masyarakat. Ini merupakan suatu upaya yang diatur melalui perundang-undangan, untuk melindungi martabat dan kesucian (misaq al-galid) Perkawinan, dan lebih khusus lagi perempuan dalam kehidupan rumah tangga. Melalui pencatatan Perkawinan yang dibuktikan dengan Akta Nikah, yang masing-masing suami-istri mendapat salinannya, apabila terjadi percekcokan diantara mereka, atau salah satu tidak bertanggung jawab, maka yang lain dapat melakukan upaya hukum guna mempertahankan atau memperoleh hak-hak masing-masing. Karena dengan akta tersebut, suami istri memiliki bukti autentik atas perbuatan hukum yang telah mereka lakukan. ${ }^{6}$

Berdasarkan penjelasan pada Pasal 49 Ayat (2) angka 22 Undang-undang tentang Peradilan Agama dan ketentuan Pasal 7 Ayat 3 huruf d Kompilasi Hukum Islam (KHI), maka dapatlah dipahami bahwa sebenarnya permohonan itsbat nikah yang dapat diajukan permohonan ke Pengadilan Agama pada dasarnya hanyalah terhadap peristiwa Perkawinan yang dilakukan atau yang terjadi sebelum berlakunya Undang-undang Nomor 1 Tahun 1974 tentang Perkawinan. Ini berarti bahwa secara a contrario atau sebuah penafsiran hukum secara terbalik (mafhum mukhalafah), Pengadilan Agama tidak berwenang untuk mengitsbatkan terhadap suatu Perkawinan yang dilangsungkan setelah terbitnya Undang-undang Nomor 1 Tahun 1974 tentang Perkawinan.

Tetapi hal ini berbeda dengan realitas yang ada mengenai fenomena itsbat nikah yang terjadi di Pengadilan Agama Andoolo dari hasil observasi yang dilakukan oleh peneliti ditemukan 245 kasus itsbat nikah dari tahun 2015 sampai dengan tahun 2017 yang kemudian akan diteliti lebih mendalam ${ }^{7}$. Jumlah keseluruhan perkara permohonan itsbat nikah yang telah diputus oleh pengadilan Agama Andoolo mulai dari tahun 2015 sampai dengan tahun 2017 terdapat 236 perkara. Dari total jumlah kasus itsbat nikah tersebut terdapat 229 perkara yang pernikahannya dilakukan pasca terbitnya Undangundang No.1 Tahun 1974 tentang Perkawinan.

Fenomena Itsbat Nikah semakin dianggap sesuatu yang lasim seiring dengan terbitnya Perma No.1 Tahun 2015 Tentang Pelayanan Terpadu Sidang Keliling Pengadilan Negeri dan Pengadilan Agama / Mahkamah Syariah Dalam Rangka

\footnotetext{
${ }^{5}$ Instruksi Presiden Republik Indonesia Nomor 1 Tahun 1991 tentang Kompilasi Hukum Islam Pasal 5

${ }^{6}$ Ahmad Rofiq, Hukum Islam di Indonesia,Ed.1. Cet. 6.- Jakarta: RajaGrafindo Persada, 2003), h. 107

${ }^{7}$ Sumber: laporan Tahunan Pengadilan Agama Andoolo, ovservasi pada tanggal 12 Juli 2017 
Penerbitan Akta Perkawinan, Buku Nikah dan Akta Kelahiran. Sehingga dengan demikian maka dengan adanya sidang keliling tersebut maka ini jelas akan mempermudah bagi masyarakat dalam rangka pelayanan administrasi dan berhak mendapatkan pengakuan hukum dengan berdasarkan pertimbangan bahwa sebagian Anggota Masyarakat terutama kelompok miskin mengalami hambatan biaya, jarak dan waktu dalam menyelesaikan proses pencatatan Perkawinan dan pencatatan kelahiran serta untuk meningkatkan pelayanan terhadap masyarakat miskin dalam memperoleh Akta Perkawinan, Buku Nikah dan Akta Kelahiran. ${ }^{8}$ Berdasarkan yang ditelah dipaparkan diatas, maka dapat diformulasikan beberapa rumusan masalah yang menjadi objek penelitian ini yakni; (1). Bagaimanakah kondisi obyektif itsbat nikah pasca terbitnya Undang-undang No. 1Tahun 1974 di Pengadilan Agama Andoolo dari tahun 2015-2017? (2). Faktor-faktor apa sajakah yang menjadi penyebab bagi pasangan suami istri mengajukan permohonan itsbat nikah pasca terbitnya UU No.1 Tahun 1974 di Pengadilan Agama Andoolo dari tahun 2015-2017? (3) Bagaimanakah pandangan Hakim Pengadilan Agama Andoolo mengenai fenomena itsbat nikah terhadap perkawinan pasca terbitnya Undang-undang No.1 Tahun 1974 di Pengadilan Agama Andoolo? (4) Dampak apa sajakah yang diakibatkan dengan adanya Itsbat Nikah terhadap Perkawinan setelah terbitnya Undang-undang Perkawinan di Pengadilan Agama Andoolo?

\section{Kajian Teori}

Menurut Ahmad Warson Munawir dalam bukunya Kamus Al-Munawir, ArabIndonesia sebagaimana yang dikutip oleh Yusna Zaidah mengatakan bahwa itsbat nikah berasal dari bahasa Arab yang terdiri dari itsbat dan Nikah. Menurut bahasa itsbat berarti "Penetapan, Pengukuhan dan Pengiyaan", dalam bahasa Indonesia dikenal dengan sebutan isbat nikah yang diartikan dengan pengukuhan dan penetapan perkawinan melalui pencatatan dalam upaya mendapatkan pengesahan suatu perkawinan menurut hukum yang berlaku ${ }^{9}$.

Selanjutnya Itsbat dalam perspektif Perma No.1 Tahun 2015 Pelayanan Terpadu Sidang Keliling pada Pasal 1 ayat (3) menyatakan bahwa; "itsbat nikah adalah pengesahan nikah bagi masyarakat beragama Islam yang dilakukan oleh Pengadilan

${ }^{8}$ Peraturan Mahkamah Agung Republik Indonesia Nomor 1 Tahun 2015 Tentang Pelayanan Terpadu Sidang Keliling Pengadilan Negeri dan Pengadilan Agama / Mahkamah Syariah Dalam Rangka Penerbitan Akta Perkawinan, Buku Nikah dan Akta Kelahiran

${ }^{9}$ Zaidah Yusna, 2013. Syariah: Jurnal Hukum dan Pemikiran, "Itsbat Nikah dalam Perspektif Kompilasi Hukum Islam hubungannya dengan kewenangan Peradilan Agama”, (online), Jurnal.uinantasari.ac.id/index.php/syariah/article/view/170, diakses 01 Desember 2017 
Agama/Mahkamah Syari'ah sesuai dengan ketentuan yang berlaku". ${ }^{10}$ Kemudian menurut Subekti $\mathrm{R}^{11}$ beliau mengatakan bahwa Perkawinan adalah merupakan hubungan pertalian yang sah antara seorang lelaki dan seorang perempuan untuk dalam jangka waktu yang lama. Sedangkan dalam KUHP pada Pasal 26 disana ditegaskan bahwa ${ }^{12}$ Undang-undang memandang bahwa Perkawinan itu hanya dari sudut hubungan keperdataan semata. Pada dasarnya itsbat nikah adalah penetapan atas perkawinan yang yang sudah dilaksanakan sesuai ketentuan Agama Islam namun tidak tercatat oleh pejabat yang berwenang. Itsbat (penetapan) merupakan produk PengadilanAgama, dan diistilahkan dengan jurisdiktio voluntair (bukan pengadilan yang sesungguhnya). Karena didalam perkara ini hanya ada pemohon dan didalamnya tidak terdapat sengketa, sehingga tidak ada lawan. Pada dasarnya perkara permohonan tidak dapat diterima, kecuali kepentingan Undang-undang menghendaki demikian. ${ }^{13}$ Jadi itsbat nikah adalah cara yang dapat ditempuh oleh pasangan suami istri yang telah menikah secara sah menurut Agama untuk mendapatkan legalitas hukum sepanjang memenuhi kriteria itsbat nikah berdasarkan peraturan perundang-undangan yang berlaku sebagaimana diatur dalam KHI Pasal 7 ayat 3. Dari penjelasan Pasal tersebut pada poin (d), jelas bahwa hal ini bertolak belakang dengan perkawinan yang terjadi setelah terbitnya UU No.1 Tahun 1974 tentang Perkawinan dan mengajukan permohonan itsbat nikah ke Pengadilan Agama. Dengan demikian, maka dalam hal ini peneliti sepaham dengan yang dinyatakan oleh Soerjono Soekanto ${ }^{14}$ bahwa kesadaran atau kepatuhan terhadap hukum sebenarnya merupakan inti daripada system budaya suatu masyarakat.

Penelitian ini membahas tentang fenomena itsbat nikah pada perkawinan yang dilakukan pasca terbitnya UU No.1 Tahun 1974 tentang Perkawinan di Pengadilan Agama Andoolo. Dengan menggunakan pendekatan yuridis-empiris,dengan berlandaskan pada beberapa teori-teori hukum yang dijadikan sebagai pisau analisis yakni diantaranya adalah teori perilaku hukum, dalam penelitian ini penulis akan memaparkan tinjauan peraturan perundang-undangan terhadap isbat nikah dan gejala fenomena sosial yang menyebabkan masyarakat tertentu melakukan penyimpangan hukum, ${ }^{15}$ maka

${ }^{10}$ Lihat : Peraturan Mahkamah Agung RI No.1 Tahun 2015, Pasal 1 ayat 3

${ }^{11}$ Subekti R, "Pokok-pokok hukum perdata", Jakarta: PT. Intermasa, 1994, h. 23

${ }^{12}$ Subekti R., "Kitab Undang-undang Hukum Perdata”, Jakarta: PT Pradnya Paramita, 2008, h. 8.

${ }^{13}$ Admin, 2016, Pengertian Itsbat Nikah, http://www.suduthukum.com/2016/02/pengertian-isbat-nikah.html, diakses 19 September 2017.

${ }^{14}$ Soerjono Soekanto,Soleman B.Taneko, "Hukum Adat di Indonesia".-Ed.1,-9,-- Jakarta: PT.RajaRafindo Persada, 2008, h. 337

${ }^{15}$ Penyimpangan hukum atau perbuatan melawan hukum dalam KUH Perdata Pasal 1365, yaitu "Tiap perbuatan melanggar hukum yang membawa kerugian kepada orang lain, mewajibkan orang yang karena salahnya menerbitkan kerugian itu, mengganti kerugian tersebut." Menurut Moegni djojodirjo, 
berlandaskan analisis penulis yang dipaparkan sebelumnya maka dapatlah dijelaskan setidaknya dua penyataan pokok, yakni: (1) hukum melalui factor pewujud, artinya bahwa yang mewujudkan suatu perilaku hukum, yakni perilaku yang sesuai dengan keinginan hukum, (2) hukum yang bertemu dengan faktor penghambat, artinya tidak mewujudkan perilaku hukum, yakni perilaku yang tidak sesuai dengan keinginan hukum itu sendiri. ${ }^{16}$

Terkait persoalan kompleksitas motif dan gagasan yang mempengaruhi perilaku hukum, Lawrence M. Fridman mengategorikan dalam empat kategori yakni yang pertama kepentingan diri sendir (self-interest), yang kedua adalah sensitive terhadap sanksi, dan yang ketiga adalah tanggapan pengaruh sosial. Serta yang ke empat adalah, kepatuhan terhadap hukum karena pelanggaran yang dilakukannya itu dinilai immoral/illegal. ${ }^{17}$ Selain teori perilaku hukum penulis kemukakan diatas, maka selanjutnya teori yang kedua adalah teori elemen system hukum. Adanya motif beserta gagasan maka hal ini mensyaratkan pengenalan hukum, karena itu adanya perilaku yang sesuai hukum tidaklah dapat dipisahkan dari pelembagaan hukum itu sendiri. Realitas ini didukung dengan rumusan hukum yang dikemukakan oleh Lawrence M. Fridman, ${ }^{18}$ yang mengatakan bahwa ada tiga macam elemen sitem hukum yang menentukan berfungsinya suatu hukum, yakni; subtance ${ }^{19}$, structur $^{20}$, dan legal culture ${ }^{21}$.

\section{Metode Penelitian}

Penelitian ini menggunakan pendekatan yuridis-empiris, Jenis penelitian yang penulis pergunakan dalam penelitian ini adalah penelitian kualitatif yang bersifat deskriptif yang mana dalam penelitian deskriptif ini bertujuan untuk menggambarkan secara tepat sifat-sifat suatu individu, keadaan, gejala atau kelompok tertentu, atau untuk

pada istilah "melawan" sudah termasuk pengertian perbuatan yang bersifat aktif maupun pasif. Lihat: Moegni Djojodirjo, Perbuatan Melawan Hukum, (Jakarta: Pradnya Paramita, 1982), h. 13

${ }^{16}$ Soleman B. Taneko, Pokok-Pokok Studi Hukum dalam Masyarakat (Jakarta: PT. Raja Grafindo Persada, 1993), h. 56

${ }^{17}$ Lawrence M. Friedman, Law and Society; An Introduction (New Jersey: Prentice Hall, 1997), h. $155-156$

${ }^{18}$ Lawrence M. Friedman, The Legal System: A Sosial Science Perspective (New York: Russel Soge Foundation, 1996), h. 16

${ }^{19}$ Substance (subtansi) adalah merupakan aturan-aturan, norma-norma dan pola perilaku nyata manusia yang berada dalam system itu termasuk produk yang dihasilkan oleh orang yang berada di dalam system hukum itu, mencakup keputusan yang mereka keluarkan atau aturan baru yang mereka susun

${ }^{20}$ Structur (struktur); merupakan kerangka, bagian yang tetap bertahan, bagian yang memberikan semacam bentuk dan batasan terhadap keseluruhan instansi-instansi penegak hukum. Di Indonesia, yang merupakan struktur dari sitem hukum antara lain; institusi atau penegak hukum seperti advokat, polisi, jaksa dan hakim.

${ }^{21}$ Legal Culture (budaya hukum) ; adalah merupakan suasana pikiran system dan kekuatan sosial yang menentukan bagaimana hukum itu dipergunakan, dihindari ataupun diselewengkan oleh masyarakat. 
menentukan penyebaran suatu gejala, atau untuk menetukan ada tidaknya hubungan antara suatu gejala dengan gejala lain dalam suatu masyarakat, dengan sudut penerapannya dalam bentuk penelitian hukum yang sosiologis. ${ }^{22}$ Yang berarti penelitian lapangan (field research) atau yang biasa juga disebut studi kasus, artinya bahwa data yang kemudian dijadikan sebagai rujukan dalam penelitian ini yakni berupa data faktafakta kasus yang terjadi dilapangan ${ }^{23}$. Dan dilaksanakan di kantor Pengadilan Agama Andoolo Kabupaten Konawe Selatan, tepatnya bagi pasangan suami istri yang mengajukan permohonan Itsbat Nikah periode 2015-2017. Masa penelitian ini dilakukan selama tiga bulan, pada bulan Desember 2017 hingga Maret 2018. Teknik pengumpulan data dilakukan dengan teknik observasi, wawancara mendalam terhadap beberapa responden, menelaah berbagai referensi dalam bentuk buku, arsip putusan/penetapan Pengadilan Agama Andoolo, website dan berbagai regulasi yang terkait dan relevan.

\section{Hasil dan Pembahasan}

Berdasarkan hasil penelitian dan wawancara yang dilakukan oleh peneliti, maka dapatlah ditarik suatu asumsi bahwa pada dasarnya kondisi obyektif mengenai Itsbat Nikah yang dilakukan pasca terbitnya Undang-undang Nomor 1 Tahun 1974 tentang Perkawinan sangat marak terjadi didalam kehidupan masyarakat. sebagaimana yang dijelaskan oleh Mohamad Arif mengatakan bahwa kondisi obyektif itsbat nikah di Pengadilan Agama Andoolo masih saja tetap ada peningkatan permohonan itsbat nikah setiap tahun, menurutnya bahwa masyarakat telah mengetahui hal tersebut bertujuan untuk mendapatkan kepastian hukum atas perkawinan yang telah dilaksanakannya namun tidak tercatat pada KUA setempat ${ }^{24}$. Berikut adalah jumlah perkara itsbat nikah yang telah diterima oleh pihak Pengadilan Agama Andoolo dari periode tahun 2015 sampai dengan tahun 2017 sebagaimana yang diuraikan dalam tabel berikut ini:

Tabel 1.1

Data Perkara Itsbat Nikah Yang diputus PA Andoolo Tahun 2015 - 2017

\footnotetext{
${ }^{22}$ Amiruddin \& Zainal Azikin, Pengantar Metode Penelitian Hukum, -Ed.1,-Cet.8-Jakarta: Rajawali Pers,2014,h.25-30 h. 87

${ }^{23}$ Iqbal Hasan, Pokok-Pokok Materi Penelitian dan Aplikasinya, (Jakarta: Graha Indonesia, 2002),

${ }^{24}$ Wawancara, pada tanggal 18 Januari 2018
} 


\begin{tabular}{|c|c|c|c|c|c|c|c|c|c|}
\hline No & Tahun & 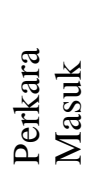 & 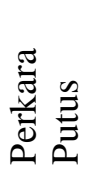 & $\begin{array}{l}\tilde{y} \\
\vec{\Xi} \\
\tilde{\Xi} \\
\ddot{ت}\end{array}$ & 章 & 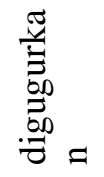 & 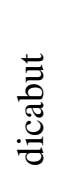 & 莺 & 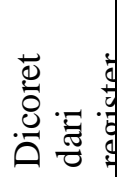 \\
\hline 1. & 2015 & 8 & 8 & 6 & & & & & \\
\hline 2. & 2016 & 13 & 13 & 07 & & & & & \\
\hline 3. & 2017 & 5 & 5 & 0 & & & & & \\
\hline Jum & & 36 & 36 & 23 & & & & & \\
\hline
\end{tabular}

Sumber data: Panmud Hukum Pengadilan Agama Andoolo, 4/1/2018

Secara umum dari jumlah perkara itsbat nikah yang diputus dan telah ingkra adalah sebanyak 236 perkara, dan terdapat 223 perkara yang dikabulkan, 3 perkara yang ditolak, kemudian ada 3 perkara yang digugurkan serta sebanyak 7 perkara yang dicabut, hal ini berdasarkan hasil pertimbangan dan putusan majelis hakim Pengadilan Andoolo dalam persidangan. Dengan berdasarkan data tersebut diatas, maka hal ini dapat dilihat bahwa pada dasarnya mayoritas yang mengajukan permohonan itsbat nikah di pengadilan Agama Andoolo adalah perkawinan yang terjadi setelah terbitnya UU Perkawinan Nomor 1 Tahun 1974. Hal ini berdasarkan dari hasil survey berkas perkara Permohonan Itsbat Nikah di Pengadilan Agama Andoolo maka dapat dilakukan kategorisasi data perkara permohonan Itsbat Nikah yang diterima dan di putus Pengadilan Agama Andoolo periode tahun 2015-2017 sebagaimana dapat dilihat dalam tabel berikut:

Tabel 1.2

Kategorisasi Data Perkara Itsbat Nikah PADA Pada Perkawinan Yang Terjadi Sebelum dan Setelah Terbitnya UU NO.1 Tahun 1974 Periode 2015 s/d 2017

\begin{tabular}{|r|r|r|r|r|}
\hline No. & $\begin{array}{r}\text { Total } \\
\text { Perkara } \\
\text { Masuk/Putus }\end{array}$ & $\begin{array}{r}\text { Sebelum } \\
\text { terbitnya UUP } \\
\text { No.1/1974 }\end{array}$ & $\begin{array}{r}\text { Setelah } \\
\text { terbitnya UUP } \\
\text { No.1/1974 }\end{array}$ & Ket. \\
\hline 1. & $\mathbf{2 3 6}$ & 6 & 230 & - \\
\hline
\end{tabular}

Berdasarkan data tersebut maka dapat diketahui bahwa terdapat 6 Perkara Itsbat Nikah yang perkawinannya terjadi sebelum terbit dan berlakunya UU No.1 Tahun 1974 serta PP No.9 Tahun 1975, dan selanjutnya terdapat 230 perkara Itsbat Nikah yang perkawinannya terjadi setelah terbitnya UU No.1 Tahun 1974 dan PP No.9 Tahun 1975. 
Agar data dapat lebih jelas dan mudah dipahami perbandingan persentase perkara secara umum yang telah diputus oleh pihak Pengadilan Agama Andoolo, maka hal ini dapat dilihat dalam Rekapitulasi Perkara yang di Putus pada periode tahun 2015 sampai dengan tahun 2017 sebagaimana yang tercantum pada tabel berikut:

Tabel 1.3

Data Rekapitulasi Perkara Yang diputus PA Andoolo Priode 2015-2017

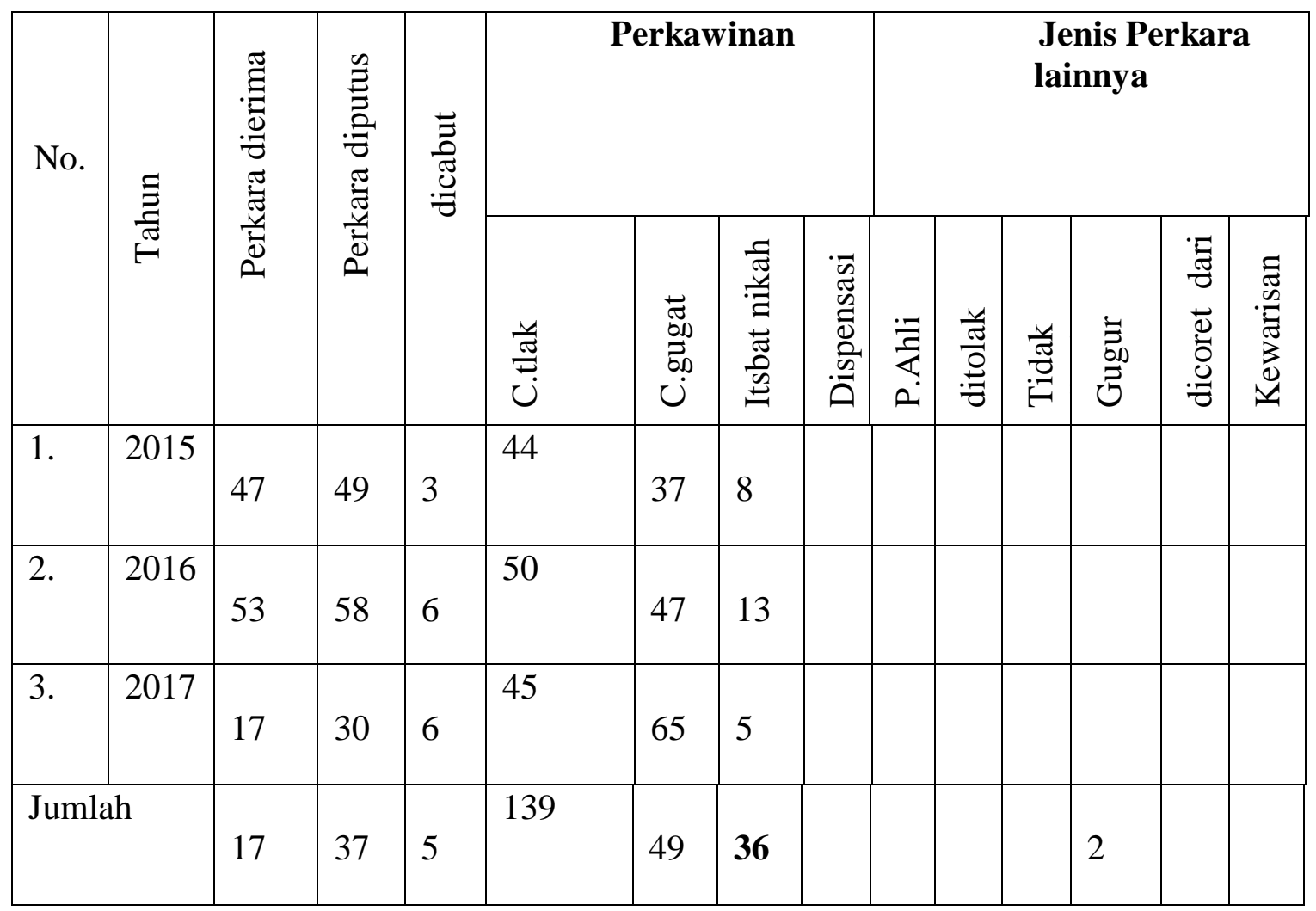

Sumber; Panmud Hukum Pengadilan Agama Andoolo, tgl. 9/3/18

Berdasarkan data tersebut diatas, menunjukkan bahwa mayoritas perkara yang mendominasi adalah kasus perceraian yang mana dalam hal ini adalah cerai gugat terdapat 449 perkara atau $45 \%$, kemudian cerai talak terdapat 139 perkara atau $19 \%$, itsbat nikah terdapat 236 perkara atau $26 \%$, dan dispensasi nikah terdapat 4 perkara atau $6 \%$, serta penetapan ahli waris terdapat 3 perkara atau $4 \%$. Masalah pencatatan perkawinan adalah merupakan masalah yang sangat krusial yang terjadi ditengah masyarakat, sekalipun Undang-undang Perkawinan menegaskan bahwa setiap perkawinan harus dicatat. Namun tidak jarang pula dijumpai masih tetap adanya peristiwa perkawinan yang terjadi ditengah kehidupan bermasyarakat tidak tercatat pada Kantor 
Urusan Agama, hal ini terbukti dengan maraknya perkara itsbat nikah yang diterima oleh Pengadilan Agama Andoolo dalam kurung waktu periode 2015 s/d $2017^{25}$.

Kemudian dalam hal pencatatan perkawinan sebagaimana yang telah diamanatkan dalam Undang-undang Perkawinan pada khakikatnya masyarakat telah mengetahui bahwa setiap perkawinan itu harus dicatat oleh pihak yang berwenang yakni pihak Kantor Urusan Agama ${ }^{26}$. Namun akan tetapi realitas ini menunjukkan bahwa tingkat kesadaran hukum masyarakat dalam hal pencatatan perkawinan masih sangat minim, hal ini pula disebabkan oleh karena pengaruh adat istiadat pada masyaraat Konawe Selatan masih sangat dominan dan kental dalam mempengaruhi kehidupan bermasyarakat terkhususnya pada masalah perkawinan. Sehingga dengan demikian maka penyelenggaraan suatu pernikahan yang terjadi lebih dominan dilaksanakan diluar Kantor Urusan Agama setempat. Hal ini dapat dilihat dalam tabel berikut:

Tabel 1.4

Data Rekapitulasi Peristiwa Nikah dan Rujuk Kemenag Kab.Konsel Priode 2015-2017

\begin{tabular}{|c|c|c|c|c|}
\hline No & Tahun & $\begin{array}{r}\text { Nikah } \\
\text { di KUA }\end{array}$ & $\begin{array}{c}\text { Nikah } \\
\text { diluar KUA }\end{array}$ & $\begin{array}{c}\text { Itsbat } \\
\text { Nikah }\end{array}$ \\
\hline 1. & 2015 & 242 & 1.585 & 0 \\
\hline 2. & 2016 & 208 & 1.662 & 160 \\
\hline 3. & 2017 & 155 & 1531 & 108 \\
\hline \multicolumn{2}{|l|}{ Jumlah } & 605 & 4.778 & 268 \\
\hline
\end{tabular}

Sumber data: Kasi Bimas Islam Kemenag Kab.Konsel

Data tersebut, menunjukkan bahwa mayoritas masyarakat melaksanakan pernikahan diluar KUA, inipula membuktikan bahwa sebagai pihak yang berwenang dalam melakukan pengawasan dan pencatatan nikah dan pelaksanaannya dilakukan oleh pihak ketiga sebagai pembantu PPN di Desa ataupun Imam Desa dengan memberikan rekomendasi terhadapnya dan sifat terbatas untuk wilayah kategori D1 dan D2 semata, ini berdasarkan Instruksi Direktur Jendral Bimbingan Masyarakat Islam yakni ${ }^{27}$; Pertama : $\quad$ Pengangkatan Pembantu Pegawai Pencatat Nikah agar dilakukan secara selektif dengan mengacu kepada Pasal 3 ayat (2) Peraturan Menteri Agama Nomor 11 Tahun 2007 tentang Pencatatan Nikah; Kedua : Rekomendasi pengangkatan Pembantu Pegawai Pencatat Nikah dari Kepala Seksi yang membidangi Urusan Agama Islam harus memperhatikan; (1). Kantor Urusan Agama Kecamatan tersebut masuk dalam tipologi

\footnotetext{
${ }^{25}$ Observasi, Penelitian Berkas Perkara Permohonan Itsbat Nikah PA Andoolo, pada tanggal 04 Januari 2018

${ }^{26}$ wawancara, pada tanggal 18 Januari 2018

27 Intruksi Direktur Jendral Bimbingan Masyarakat Islam Nomor DJ.II/I tahun 2015 tentang pengangkatan Pembantu Pegawai Pencatat Nikah.
} 
D1 (daerah di pedalaman dan atau wilayah pegunungan) dan D2 (daerah terluar/perbatasan negara, dan atau kepulauan) yang ditetapkan oleh Kepala Kantor Wilayah Kementerian Agama Provinsi dan tidak dapat dijangkau oleh Pegawai Pencatat Nikah karena terbatasnya Sumber Daya Manusia (SDM) disbanding dengan luas wilayah; (2). Pembantu Pegawai Pencatat Nikah berdomisili di desa dimaksud; (3). Kemampuan dan Kompetensi calon Pembantu Pegawai Pencatat Nikah di bidang hukum dan administrasi pernikahan,

Dengan dasar intruksi tersebut menunjukkan bahwa Pembantu PPN di desa sudah tidak ada lagi terkecuali terbatas pada kedua kategori wilayah yang dimaksud. Akan tetapi mayoritas dari mereka (masyarakat) masih mempercayakan pengurusan administrasi kepada pembantu PPN yang ada di desa, sebagaimana lasimnya yang bertugas sebagai pembantu PPN adalah Imam Desa yang dianggap sebagai tokoh adat ataupun tokoh Agama. Padahal didalam PP No.9 Tahun 1975 Pasal 10 ayat 3 menyatakan bahwa :

"Dengan Mengindahkan tatacara perkawinan menurut masing-masing hukum Agamanya dan kepercayaannya itu, perkawinan dilaksanakan dihadapan Pegawai Pencatat dan dihadiri oleh dua orang saksi",28.

Peneliti berasumsi bahwa hal ini jelas apa yang telah dilakukan oleh mereka yang melangsungkan perkawinan itu bertentangan dengan tatacara perkawinan berdasarkan PP No.9 Tahun 1975 tersebut diatas karena yang bertindak sebagai penghulu atau PPN bukan petugas resmi pemerintah yang lebih berkompoten dibidangnya. Kemudian selanjutnya dalam Pasal 11 dinyatakan ${ }^{29}$ : (1). Sesaat sesudah dilangsungkannya perkawinan sesuai dengan ketentuan-ketentuan Pasal 10 Peraturan Pemerintah ini, kedua mempelai menanda tangani akta perkawinan yang telah disiapkan oleh Pegawai Pencatat berdasarkan ketentuan yang berlaku. (2). Akta perkawinan yang telah ditanda tangani oleh mempelai itu, selanjutnya ditandatangani pula oleh kedua saksi dan pegawai pencatat yang menghadiri perkawinan dan bagi yang melangsungkan perkawinan menurut Agama Islam, ditandatangani pula oleh wali nikah atau yang mewakilinya. (3). Dengan penandatangan akta perkawinan, maka perkawinan tercatat secara resmi.

Berdasarkan penjelasan Pasal 11 tersebut, maka ketika suatu perkawinan dilangsungkan tanpa ada buku nikah yang ditandatangani oleh calon mempelai, yang mana hal tersebut dilaksanakan oleh Imam Desa atau Pembantu PPN maka peneliti berasumsi bahwa tatacara perkawinan yang dilangsungkan oleh mereka itu tidak mengikuti prosedur sebagaimana yang telah ditetapkan dalam PP No.9/1975 ini. Oleh sebab itu peneliti berasumsi bahwa semestinya yang memiliki peranan penuh dalam

\footnotetext{
${ }^{28}$ Peraturan Pemerintah RI No.9 Tahun 1975 tentang Pelaksanaan Undang-undang No.1 Tahun 1974 Tentang Perkawinan, Pasal 10 ayat (3)

${ }^{29}$ Pasal 11 ayat (1-3)
} 
melaksanakan tugas pengawasan dan pencatatan nikah itu adalah Pejabat Resmi Negara yang benar-benar berkonpoten dibidangnya serta memahami tugas dan tanggungjawabnya sebagai aparatur sipil negara sebagaimana yang dimaksud pada Pasal 2 ayat (1) dan (2) Peraturan Menteri Agama yang menyatakan bahwa; (1). Pegawai Pencatat Nikah yang selanjutnya disebut PPN adalah pejabat yang melakukan pemeriksaan persyaratan, pengawasan dan pencatatan peristiwa nikah/rujuk, pendaftaran cerai talak, cerai gugat, dan melakukan bimbingan perkawinan. (2). PPN dijabat Oleh Kepala KUA ${ }^{30}$.

\section{Faktor-Faktor Penyebab Pasangan Suami Istri Mengajukan Permohonan Itsbat Nikah}

Menurut Amir Nuruddin dan Azhari Akmal Tarigan mengatakan bahwa pencatatan perkawinan tidak diberi perhatian oleh fiqhi walaupun ada ayat Al-Qur'an yang menganjurkan untuk mencatat segala bentuk transaksi muamalah disebabkan oleh beberapa hal diantaranya adalah pertama, adanya larangan untuk menulis sesuatu selain Al-Qur'an, kedua, menggandalkan hafalan(ingatan), ketiga, tradisi walimat al-urusy, keempat ada kesan perkawinan dimasa awal Islam belum terjadi antar wilayah negara yang berbeda. Sehingga alat bukti kawin selain saksi belum dibutuhkan.

Dengan demikian pencatatan perkawinan ini walaupun di dalam UUP hanya diatur oleh satu ayat namun masalah pencatatan ini sangat dominan. Sehingga menurutnya bahwa tidaklah berlebihan jika ada sementara pakar hukum yang menempatkannya sebagai syarat administratif yang juga menentukan sah tidaknya sebuah perkawinan $^{31}$. Meskipun, Peraturan Perundang-Undangan sudah mengharuskan adanya Akta Nikah sebagai bukti perkawinan, namun tidak jarang terjadi suami istri yang telah menikah akan tetapi tidak mempunyai Kutipan Akta Nikah. Adapun yang menjadi penyebab tidak adanya Kutipan Akta Nikah disebabkan oleh beberapa faktor seperti; (a).Kawin secara terpaksa atau kawin tanpa persetujuan keluarga, (b). Masyarakat belum paham Pencatatan Nikah di $\mathrm{KUA}^{32}$, (c). Kesadaran masyarakat yang minim pentingnya buku nikah $^{33}$. (d). Kondisi jarak yang jauh dan sulit ditempuh menuju KUA ${ }^{34}$.

Dari beberapa kasus dalam penjelasan mengenai kondisi obyektif itsbat nikah bagi pasangan suami istri yang diajukan pada Pengadilan Agama Andoolo, maka yang menjadi

\footnotetext{
${ }^{30}$ Peraturan Menteri Agama Republik Indonesia Nomor 11 Tahun 2007 tentang Pencatatan Nikah, Pasal 2 ayat (1-2)

${ }^{31}$ Amiur Nuruddin dan Azhari Akmal Tarigan, Hukum Perdata Islam di Indonesia: Studi Kritis Perkembangan Hukum Islam dari Fikih, UU No.1/1974 sampai KHI”, Edisi Pertama, Cet. Ke-5, Jakarta: Kencana Prenadamedia Group, 2014, h.120-121

${ }^{32}$ Wawancara, pada tanggal 05 Maret 2018

${ }^{33}$ Wawancara, pada tanggal 12 Maret 2018

${ }^{34}$ Wawancara, pada tanggal 09 Maret 2018
} 
faktor penyebab bagi pasangan suami istri tersebut sehingga mereka mengajukan permohonan itsbat nikah, pada umumnya itu disebabkan oleh berbagai macam hal, diantaranya ${ }^{35}$ : (a). Faktor kondisi ekonomi, tidak adanya kutipan akta nikah bagi pasangan suami istri yang telah menikah dengan alasan tidak mampu secara ekonomi, (b). Adanya kelalaian Petugas yang mana dalam hal ini adalah petugas PPPN/Imam Desa yang ada di Desa yang tidak menyetor berkas calon pengantin pada KUA setempat.

Hal yang berbeda dengan apa yang dinyatakan oleh Muhamad Arif dan Abdul Hafid bahwa beberapa faktor penyebab masyarakat mengajukan permohonan itsbat nikah di Pengadilan Agama disebabkan karena: (a).Kelalaian masyarakat itu sendiri tidak mencatatkan perkawinannya pada instansi yang berwenang, dalam hal ini adalah KUA Setempat, (b). Biaya yang tinggi sehingga masyarakat enggan untuk mencatatkan perkawinannya itu, (c). Adanya suatu perkawinan yang tidak normal (masalah adat), misalnya kawin lari dari keluarga, kawin paksa oleh pihak keluarga ataupun dalam keadaan telah hamil ${ }^{36}$. Menurut Derliati dan Tamsil bahwa alasan utama mereka mengajukan permohonan itsbat nikahnya adalah; karena tidak adanya buku nikah yang dikeluarkan oleh pihak KUA tempat mereka melangsungkan perkawinannya itu, yang kesemuanya telah diserahkan dan dipercayakan kepada petugas Imam Desa atau PPPN dengan melunasi biaya administrasi pencatatan nikah tersebut dan pada akhirnya Imam Desa yang menikahkannya itu telah wafat ${ }^{37}$.Berdasarkan hasil temuan dilapangan mengenai faktor penyebab bagi pasangan suami istri mengajukan perkara permohonan itsbat nikah pada Pengadilan Agama Andoolo pada dasarnya disebabkan oleh karena berbagai macam, hal ini dapat dilihat diantaranya adalah: (1). Alasan ekonomi tidak mampu, biaya pencatatan perkawinan yang mahal sehingga masyarakat sebagai calon pengantin tidak mendaftarkan pencatatan perkawinannya pada KUA setempat, (2). PPPN/Imam di desa yang tidak menyetor berkas pada KUA,

Faktor tidak mampu secara ekonomi untuk membayar biaya pendaftaran nikah, menurut hemat penulis bahwa, hal ini sudah tidak relevan dengan realitas yang ada saat ini. Sebab dengan terbitnya PP No.48 Tahun 2014 tentang perubahan atas Peraturan Pemerintah No.47 Tahun 2004 tentang Tarif Atas Jenis Penerimaan Negara Bukan Pajak Yang Berlaku Pada Departemen Agama telah digratiskan berdasarkan pada Pasal 6 ayat (1-3) menyatakan bahwa ${ }^{38}$ :

\footnotetext{
${ }^{35}$ Wawancara pada tanggal 17 Januari 2018

${ }^{36}$ Wawancara pada tanggal 07 Maret 2018

${ }^{37}$ Wawancara pada tanggal 25 Januari 2018

${ }^{38}$ Lihat; Peraturan Pemerintah RI No.48 Tahun 2014 tentang Perubahan atas PP No.47 Tahun 2004 tentang Tarif atas Jenis PBNP yang berlaku pada Departemen Agama, Pasal 6 ayat (1-3).
} 
1. Setiap warga negara yang melaksanakan nikah atau rujuk di Kantor Urusan Agama Kecamatan atau diluar Kantor Urusan Agama Kecamatan tidak dikenakan biaya pencatatan nikah atau rujuk.

2. Dalam hal nikah atau rujuk dilaksanakan diluar Kantor Urusan Agama Kecamatan dikenakan biaya transfortasi dan biaya profesi sebagai penerimaan dari Kantor Urusan Agama Kecamatan.

3. Terhadap warga negara yang tidak mampu secara ekonomi dan / atau korban bencana yang melaksanakan nikah atau rujuk diluar Kantor Urusan Agama Kecamatan sebagaimana dimaksud pada ayat (2) dapat dikenakan tarif Rp.0,00 ( nol rupiah).

Berdasarkan penjelasan pada Pasal tersebut diatas maka dapat dipahami bahwa sejak terbitnya PP ini, semestinya sudah tidak ada lagi perkawinan yang tidak tercatat di Kantor Urusan Agama sehingga kemudian akan meminimalisir terjadinya permohonan itsbat nikah di Pengadilan Agama Andoolo. Namun akan tetapi realitas yang ada, masih saja terjadi permohonan itsbat nikah yang perkawinannya dilaksanakan setelah terbitnya PP No.48 Tahun 2014 itu sendiri, terdapat sekitar 19 pasangan suami istri mengajukan permohonan itsbat nikah di Pengadilan Agama Andoolo yang pernikahanya terjadi antara periode tahun $2015 \mathrm{~s} / \mathrm{d} 2016^{39}$.

Kemudian selanjutnya adalah terkait dengan faktor kelalaian petugas PPPN yang ada di Desa, maka dalam hal ini peneliti berasumsi bahwa semestinya yang menjalankan tugas untuk melakukan pengawasan dan pencatatan nikah oleh negara dalam hal ini adalah aparatur sipil negara/Penghulu pada Kantor Urusan Agama Kecamatan bukan pembantu PPN di Desa, sehingga lebih pro aktif dan bertanggungjawab dalam menjalankan tugas dan kewajibannya itu, tanpa harus memberikan wewenang penuh dengan memberikan rekomendasi/mandat kepada PPPN/Imam Desa dalam rangka untuk melaksanakan tugas pengawasan dan pencatatan perkawinan di desa, meskipun hal ini diatur dalam salah salah satu regulasi sebagaimana yang dinyatakan pada Pasal 3 ayat 1 Peraturan Menteri Agama RI Nomor 11 Tahun 2017 bahwa; PPN sebagaimana yang dimaksud dalam pasal 2 ayat (1) dalam melaksanakan tugasnya dapat diwakili oleh Penghulu atau Pembantu PPN ${ }^{40}$.

\footnotetext{
${ }^{39}$ Sumber data; Hasil Penelitian Berkas Perkara Permohonan Itsbat Nikah Pada Ruang Arsip Pengadilan Agama Andoolo, tgl. 04/01/2018

${ }^{40}$ Peraturan Menteri Agama Republik Indonesia Nomor 11 Tahun 2007 tentang Pencatatan Nikah, Pasal 3 ayat (1)
} 


\section{Pandangan Hakim Pengadilan Agama Andoolo Mengenai Fenomena Itsbat Nikah Pasca Terbitnya UU No.1 Tahun 1974}

Dari hasil penelitian dan wawancara yang peneliti lakukan dilapangan, bahwa fenomena itsbat nikah yang marak terjadi ditengah masyarakat saat ini terkhususnya dalam yurisdiksi Pengadilan Agama Andoolo maka menurut Abdul Hafid bahwa; masyarakat yang mengajukan permohonan itsbat nikah di Pengadilan Agama Andoolo tetap dilayani dengan syarat melampirkan kartu keluarga, KTP, kemudian perkawinannya itu berusia diatas satu tahun sepanjang memenuhi unsur syarat dan rukun perkawinan dengan tujuan untuk mencapai kemaslahatan ${ }^{41}$ dengan menghilangkan kesulitan yang dihadapi oleh masyarakat.

Hal ini sesuai dengan Kaidah Fikih Asasi yang tingkat kesahihannya diakui oleh seluruh aliran hukum Islam yakni "kesulitan harus dihilangkan"42. Apatalagi dengan adanya program Mahkamah Agung RI yang memberikan kewenangan praktek sidang diluar gedung berdasarkan Perma No. 1 Tahun 2015 tentang Pelayanan Terpadu Sidang Keliling Pengadilan Negeri dan Pengadilan Agama/Mahkamah Syari'ah dalam Rangka Penerbitan Akta Perkawinan, Buku Nikah, dan Akte Kelahiran, maka hal ini merupakan suatu tantangan yang berat bagi aparat penegak hukum. Kemudian ada pula itsbat nikah yang ditolak oleh majelis hakim ketika hal itu tidak memenuhi syarat yang telah ditetapkan dalam undang-undang dan Kompilasi Hukum Islam itu sendiri atau tidak dapat meyakinkan hakim dan memenuhi bukti perkawinannya.

\section{Dampak Itsbat Nikah Terhadap Perkawinan Setelah Terbitnya UU Perkawinan di Pengadilan Agama Andoolo}

Sebagaimana yang penulis kemukakan sebelumnya, bahwa akar masalah sesungguhnya terjadinya itsbat nikah ini adalah disebabkan oleh karena adanya suatu peristiwa perkawinan yang tidak dapat dibuktikan dalam bentuk kutipan akta nikah bagi pasangan suami istri yang disebabkan karena perkawinannya yang tidak tercatat pada Kantor Urusan Agama setempat. Karena itu, maka kompilasi Hukum Islam memberikan solusi sebagaimana dalam Pasal 7 ayat 2 menyatakan bahwa; "Dalam hal perkawinan tidak dapat dibuktikan dengan akta nikah, dapat diajukan itsbat nikah ke Pengadilan Agama"43.

Suatu permohonan Itsbat Nikah akan berdampak positif bagi masyarakat pencari keadilan ketika permohonannya itu dikabulkan oleh pengadilan, yaitu; Pertama,

\footnotetext{
${ }^{41}$ Wawancara, pada tanggal 17 Januari 2018

${ }^{42}$ Jaih Mubarok; "Kaidah Fiqh: Sejarah dan Kaidah-Kaidah Asasi”.-Ed.1.,Cet.1. Jakarta: PT RajaGrafindo Persada, 2002. H. 105

${ }^{43}$ Lihat; Kompilasi Hukum Islam, Pasal 7 ayat 2
} 
mendapatkan kepastian hukum atas perkawinan yang dilaksanakan; Kedua, adanya pengakuan negara terhadap perkawinan tersebut dalam bentuk bukti autentik putusan hakim dengan dikabulkannya permohonan penetapan keabsahan nikah dan mendapatkan buku nikah; Ketiga, adanya perlindungan terhadap hak-hak kaum perempuan sebagai seorang istri.

Selain dampak positif ketika suatu perkara permohonan Isbat Nikah itu dikabulkan, maka tentunya tidak akan menutup cela adanya dampak negatif yang ditimbulkan, yaitu, Pertama, masyarakat beranggapan bahwa Isbat Nikah itu mudah dilakukan di pengadilan agama; Kedua, orang yang tidak mencatat pernikahannya pada instansi yang berwenang itu artinya tidak menyadari hakikat Agama, yakni kedamaian, ketentraman, kepastian hukum, dan menghindari perselisihan.

\section{Penutup}

Kondisi obyektif Itsbat Nikah pasca terbitnya Undang-undang No.1 Tahun 1974 di Pengadilan Agama Andoolo periode tahun 2015-2017 pada dasarnya fluktuatif, adapun Faktor-faktor yang menjadi penyebab bagi pasangan suami istri mengajukan permohonan itsbat nikah pasca terbitnya Undang-undang No.1 Tahun 1974 di Pengadilan Agama Andoolo adalah tidak adanya buku Nikah/Akta Nikah, sehingga terkendala masalah administrasi kependudukan dan catatan sipil. Pandangan mayoritas hakim Pengadilan Agama Andoolo mengenai fenomena itsbat nikah adalah pada dasarnya itsbat nikah boleh saja dilakukan oleh masyarakat dan tidak bisa dilarang, serta tetap dilayani apabila mengajukan permohonan itsbat di Pengadilan Agama, sebab itsbat nikah ini sangat dibutuhkan oleh masyarakat selama memenuhi rukun dan syarat perkawinan, serta dapat membuktikan perkawinannya itu dalam persidangan. Karena itu semestinya pasca terbitnya Undang-undang Perkawinan ini sudah tidak ada lagi yang mengajukan perkara permohonan itsbat nikah di Pengadilan Agama. Namun dengan pertimbangan kemaslahatan ummat, maka hakim mengambil dasar hukum berdasarkan ketentuan Pasal 7 ayat (3) huruf (e) Kompilasi Hukum Islam.Dampak yang diakibatkan dengan adanya Itsbat Nikah terhadap Perkawinan setelah terbitnya Undang-undang Perkawinan di Pengadilan Agama Andoolo ada dua macam, yakni berdampak positif dan negatif.

\section{DAFTAR PUSTAKA}

Abdul Manan, Aneka Masalah Hukum Perdata Islam di Indonesia, Cet. Ke-1, Jakarta: Kencana Prenadamedia Group,2006. 
Ahmad Rofiq, Hukum Islam di Indonesia,Ed.1. Cet. 6.- Jakarta: RajaGrafindo Persada, 2003.

Amiur Nuruddin \& Azhari Akmal Tarigan, "Hukum Perdata Islam di Indonesia: Studi Kritis Perkembangan Hukum Islam dari Fikih, UUNo.1/1974 sampai KHI", Edisi Pertama, Cet.ke-5, Jakarta: Kencana Prenadamedia Group, 2014.

Amiruddin \& Zainal Azikin, Pengantar Metode Penelitian Hukum, -Ed.1,-Cet.8-Jakarta: Rajawali Pers, 2014

Admin, 2016, Pengertian Itsbat Nikah, (online), http://www.suduthukum.com/2016/02/pengertian-isbat-nikah.html, diakses 19 September 2017

Iqbal Hasan, Pokok-Pokok Materi Penelitian dan Aplikasinya. Jakarta: Graha Indonesia, 2002;

Jaih Mubarok. Kaidah Fiqh:Sejarah dan Kaidah-kaidah Asasi, Ed.1.,Cet.1. Jakarta: PT RajaGrafindo Persada, 2002.

Lawrence M. Friedman, Law and Society; An Introduction. New Jersey: Prentice Hall, 1997;

Lawrence M. Friedman, The Legal System: A Sosial Science Perspective. New York: Russel Soge Foundation, 1996.

Subekti R, "Pokok-pokok hukum perdata”, Jakarta: PT. Intermasa, 1994

Subekti R., “Kitab Undang-undang Hukum Perdata”, Jakarta: PT Pradnya Paramita, 2008

Soerjono Soekanto,Soleman B.Taneko, “Hukum Adat di Indonesia”.-Ed.1,-9,- Jakarta: PT.RajaRafindo Persada, 2008

Soleman B. Taneko, Pokok-Pokok Studi Hukum dalam Masyarakat (Jakarta: PT. Raja Grafindo Persada, 1993),

Moegni Djojodirjo. Perbuatan Melawan Hukum, (Jakarta: Pradnya Paramita, 1982)

Zaidah Yusna, 2013. Syariah: Jurnal Hukum dan Pemikiran, "Itsbat Nikah dalam Perspektif Kompilasi Hukum Islam hubungannya dengan kewenangan Peradilan Agama", (online), Jurnal.uin-antasari.ac.id/index.php/syariah/article/view/170, diakses 01 Desember 2017

Intruksi Presiden Republik Indonesia Nomor 1 Tahun 1991 Tentang Kompilasi Hukum Islam

Peraturan Pemerintah RI No.9 Tahun 1975 tentang Pelaksanaan Undang-undang Nomor 1 Tahun 1974 Tentang Perkawinan

Undang-Undang R. I Nomor 7 Tahun 1989 sebagaimana yang telah diubah menjadi Undang-undang Nomor 3 Tahun 2003 dan Perubahan Kedua Menjadi Undangundang Nomor 50 Tahun 2009 Tentang Peradilan Agama.

Undang-undang Republik Indonesia Nomor 1 Tahun 1974 tentang Perkawinan

Undang-undang Republik Indonesia Nomor 22 Tahun 1946 tentang Pencatatan Nikah

http://advokatkita.com/syarat-mengajukan-itsbat-nikah, tgl.14/02/2018. 